\begin{tabular}{l} 
I2/2020 ISSN 2308-9636. Юридична Украӥна. 2020. № 12 \\
ІНФОРМАЦЙНЕ ПРАВО \\
\hline \hline
\end{tabular}

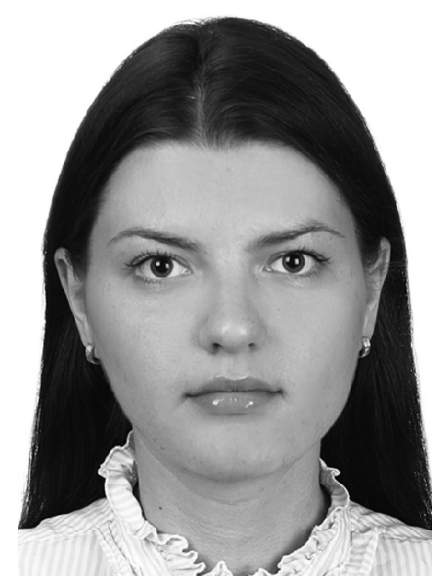

\author{
M. V. Zhuravel, \\ Bachelor of Laws Yaroslav Mudryi National Law \\ University, Ukraine, LL.M in International \\ Corporate Governance and Financial Regulation, \\ University of Warwick, United Kingdom
}

\title{
THE TRANSITION FROM TRADITIONAL TO VIRTUAL COURTS: REALITY OR MYTH FOR THE JUSTICE SYSTEM IN UKRAINE?
}

The COVID-19 pandemic has presented difficulties in jurisdictions across the world and accelerated the digitalisation processes of justice. While the world experienced massive distress and healthcare systems worldwide could hardly cope with an increasing number of coronavirus patients, the justice system was also presented with numerous challenges during the various national lockdowns. Since upholding the rule of law through access to justice in a fair trial should under no circumstances be halted, courtrooms remained opened even though these doors had to be virtual or accessed with electronic keys, as was the case in Ukraine. The earlier concept of ESITS and the E-court could have served useful purpose during this time of crisis but it failed due to technical and implementation issues and judges, therefore, had to explore other means to conduct hearings remotely. This article aims to address the situation which Ukrainian courts faced during the time of the pandemic, making reference to foreign practises in the UK and China and concluding with the prospects for virtual justice in Ukraine.

Key words: justice system, ESITS, E-court, virtual hearings, traditional courts, Online Court, COVID-19 pandemic, Smart Courts, digitalisation.

\section{Introduction}

In his presentation 'Guarantor of Innovation: creating the future together' at the 2019 iForum, Volodymyr Zelensky, expressed his digital dream - creating a state in a smartphone. ${ }^{1}$ It did not take long until the President's dream started to become a reality, as due to the COVID-19 epidemic in the following year our lives were locked into smartphones and other electronic communication devices. From working remotely from home to taking legal action with a click of the computer mouse - it all became possible within a short period of time. Clearly, the cause of such relocation was never the President's wish, but the COVID-19 pandemic crisis, which impacted the world including Ukraine, paved the way for advances in technology. Indeed, but for the already

1 'I dream about the state in a smartphone - Volodymyr Zelensky' (23 Maу 2019) «Я мрію про державу у смартфоні - Володимир Зеленський» <https://www.president.gov.ua/news/ya-mriyu-proderzhavu-u-smartfoni-volodimir-zelenskij-55585> accessed 23 January 2021. 
available technology, the world would have been halted and dragged years back in time. However, the reality in the Ukrainian courts was not so optimistic as it may have seemed at first glance, not only because of the backlogs and for the adjournment of hearings, but also due to insufficient technical equipment in the courts to serve justice remotely. In addition, there was a lack of a unified approach to the virtual hearings as well as an absence of a single electronic system which would provide effective access to justice remotely.

In the first part we will look at the challenges which the Ukrainian justice system encountered during the lockdown in March and in its aftermath. The not yet fully implemented ESITS with its subsystem of the E-court will be considered, as well as the means which were deployed for the virtual hearings. The second part of the article will explore the UK and China's experiences in virtual hearings during the pandemic. A conclusion will be drawn at the end of the article.

\section{Remote access to justice in Ukraine during the pandemic}

When the COVID-19 pandemic reached Ukraine, the Supreme Council of Justice advised courts to adhere to the Regulation of the Government of Ukraine No. 211 dated 11 March 2020 with regard to enforcement of the lockdown in order to prevent the spread of coronavirus COVID-19. ${ }^{2}$ At the same time, they gave their own recommendations to judges, including conducting trials remotely via the Internet, limiting access of members of the public who were not participants in a case, and allowing the parties in the case to know about the option for postponing the hearing due to the quarantine measures. ${ }^{3}$ At that time, however, courts facing the entirely new situation did not unanimously agree on a suitable approach to work. Different courts independently decided upon opening times, access to court buildings, method of submission of documents as well as mode for hearings. Most hearings were still conducted in a traditional way except that access to court buildings was limited for the general public with measures such as taking body temperature and requirements for masks and gloves being put in place for visitors. The Law of Ukraine 540-IX dated 30 March 2020 'About amendment to certain legal acts in respect with provision of additional social and economic guarantees in relation with coronavirus (COVID-19) spread' gave a further green light to virtual hearings conducted by electronic means for the duration of the lockdown. This legal act amended court procedures and enabled participants to take part in case hearings remotely outside of the courts by using their own technical facilities. ${ }^{4}$ The concept of an electronic court system in Ukraine had, in fact, been established in 2017 by the release of new editions of the Procedural Codes which introduced the possibility for virtual justice in Ukraine. ${ }^{5}$ So-called ESITS, with the E-court as one of the system's

2 The Regulation of the Government of Ukraine № 211 dated 11 March 2020 'About prevention the spread of COVID-19 caused by coronavirus SARS-CoV-2 in the territory of Ukraine'/Постанова Кабінету Міністрів України від 11 березня 2020 р. № 211 «Про запобігання поширенню на території України гострої респіраторної хвороби COVID-19, спричиненої коронавірусом SARS-CoV-2» <https://zakon. rada.gov.ua/laws/show/211-2020-п\#Text> accessed 23 January 2021.

3 See the Supreme Council of Justice official website: <https://hcj.gov.ua/news/vrp-nadala-sudamrekomendaciyi-hchodo-zabezpechennya-stabilnoyi-roboty-v-umovah-karantynu> accessed 21 January 2021.

4 The Law of Ukraine 540-IX dated 30 March 2020 'About amendment to certain legal acts in respect with provision of additional social and economic guarantees in relation with coronavirus (COVID-19) spread'/Закон України 540-XI «Про внесення змін до деяких законодавчих актів України, спрямованих на забезпечення додаткових соціальних та економічних гарантій у зв'язку з поширенням коронавірусної хвороби (COVID-19)" <https://zakon.rada.gov.ua/laws/show/540-20\#Text> accessed 21 January 2021.

5 Andriy Arsiriy, 'Theory vs in practice: abilities of ESITS and «Electronic court»' Yurydychna Gazeta online (24 November 2020)/Андрій Арсірій «В ідеалі vs на практиці: можливості ЄCITC та «Електронного суду» Юридична Газета online (24 листопада 2020 р.) <https://yur-gazeta.com/publications/ practice/sudova-praktika/v-ideali-vs-na-praktici-mozhlivosti-esits-ta-elektronnogo-sudu.html >accessed 24 January 2021. 
modules, was created with the goal of improving the efficiency of the justice system of Ukraine by integrating modern technology into day-to-day process, so that communication between the court and its participants could be optimized through efficient document exchange and minimization of court fees.

ESITS is designed to have a number of functions including document management processes, virtual hearings and automatic appointment of judges for trials. In order to send the documents to court, a participant has to register his or her email address in the system, on a particular website, whereby registration of certain groups of persons, such as advocates, notaries, court experts, state bodies, local governments and economic entities of the state and municipal sectors of the economy is mandatory. ${ }^{6}$ To submit the documents or perform other procedural action, the parties have to use their own electronic digital signatures. ${ }^{7}$

Although ESITS and E-courts went 'on trial' in 2019 through some of the local and appeal courts, the system received criticism from judges and was put on hold. In November 2019 ESITS was updated, however it was not implemented due to a number of factors including the instability of the software system. ${ }^{8}$ To make a change to the situation, it was decided to bring the project into action on a module-by-module basis; however until December 2020 there still was no action from the Parliament to regulate its operation. ${ }^{9}$

In theory, ESITS had started functioning but in practice it was neither efficient nor effective. For instance, Oleh
Trohymchyk, counsel for a Ukrainian regional law firm, pointed out a number of technical issues which the system encountered, such as absence of default documents and templates and the impossibility of creating a document from scratch; typed text of the document sometimes could not be saved. ${ }^{10}$ There was a further concern in relation to secure storage and protection of confidential information. In addition to these matters, there were some discrepancies with regard to the electronic digital signatures which, in some instances, could not be checked by the electronic system and therefore, a court had to advise to proceed with submission of documents in person. ${ }^{11}$ In addition, electronic digital signatures are difficult to obtain. Furthermore, in order to process the electronic digital signature, a somewhat cumbersome procedure has to be followed, whereby a person has to prepare necessary documents, apply for the certificate of a key of the electronic digital signature and further apply to a certain office for certification. Apart from this, the duration of the certificate's validity is limited to a year or two years which may be inconvenient. And yet, the electronic digital signature is an essential component to gain access to virtual justice. ${ }^{12}$ Owing to the complexities in obtaining the certificate, not everyone, therefore, is able to have access to the electronic justice at the present time.

Clearly, at this stage, ESITS is not meeting its goals but doing quite the opposite by in fact slowing down the work of lawyers and causing obstacles in their day-to-day operations. Fortunately, there

\footnotetext{
6 Step-by-step Instructions for registration in E-court <https://zp.arbitr.gov.ua/sud5009/gromadyanamel -sud-reg/> accessed 24 January 2021.

7 Ibid.

8 Olena Roshchenko, “"Electronic court) will be released in parts: Rada allowed’ Ukrainian Truth (16 December 2020)/ «Електронний суд» запускатимуть частинами: Рада дозволила» Украӥнська Правда (16 грудня 2020 р.) <https://www.pravda.com.ua/news/2020/12/16/7277151/> accessed 20 January 2020.

9 Ibid.

10 'Electronic queue' Court Messenger 4 (29 Мау 2020) / «Електронна черга» Судовий Вісник 4 від 29 травня 2020 p.

11 Ibid.

12 Dmytro Trut, Anastasia Avtuh ‘Advantages of electronic justice. We are going on time!' Lawyer \& Law/Liga 45/ Дмитро Трут, Анастасія Автух «Переваги електронного судочинства. Ідемо в ногу з часом!» Юрист \& Закон Ліга <https://uz.ligazakon.ua/ua/magazine_article/EA009834> accessed 22 January 2021.
} 
are alternative means such as video conferencing and one of them which serves a purpose has been EasyCon. It allows hearings to be conducted with respect to social distancing rules in small and large groups of people. According to Iryna Didenko, a prosecutor in Lviv Oblast, this programme prevented gatherings of more than ten people in a courtroom during the pandemic as well as facilitating attendance of participants who live far off, thus saving their travel expenses. ${ }^{13}$

The State Court Administration of Ukraine enacted the Order dated 8 April $2020^{14}$ which set the procedural steps for using EasyCon for videoconferencing. A participant has to register in the system on the official website of the Ministry of Justice of Ukraine by using their own electronic signature. They should then make a court application no later than 5 days before the trial. Having received an application, the senior judge makes a decision for video conferencing and informs the parties of the decision via emails or a phone call. Electronic signature plays an instrumental role in allowing the participants to take part in the trial since together with presenting a passport it serves as proof of a participant's identity. However, EasyCon is not without disadvantages. As Talina Kravtsova, a partner of a regional law firm, opines that it is a pity that mobile phones or tablets cannot be used because of their technical specification in this process while personal computers are not yet in the possession of every citizen in this country, which, of course, hinders their access to virtual trials. ${ }^{15}$ Furthermore, because of EasyCon being the only source for videoconferencing mentioned in the Order, it raised questions about creating a monopoly and the State Court Administration had to amend the Order ${ }^{16}$, so its terms now include other means for videoconferencing, entitling the courts to lawfully use alternatives such as Zoom or Skype for virtual hearings. However, Zoom and Skype present their own shortcomings for remote trials. For instance, a video call on Zoom has its own time limitations whereas Skype raises some concerns related to privacy. Nevertheless, being able to have an alternative for video conferencing in times of crisis is of assistance to judges.

II. With reference to some foreign practices: the UK and China

When building the framework, it is important to consider international practice in this field as well as learn from them. When the pandemic hit the world, some countries were more prepared than others to embrace the changes brought up due to a number of factors including, their technological advances and already established digital practices in the justice system as well as their cultural approaches to the sudden and drastic change.

Taking the United Kingdom as an example, the Ministry of Justice adopted a holistic approach to tackling the issue of backlogs and enabling the courts to continue delivering justice in a smooth,

13 Vladyslav Obuh 'How does the electronic justice work or 'Stand up! Court is on the line!' (30 April 2020) Ukrinform / Владислав Обух «Як працює судочинство або «Встати! Суд на звязку» Укрінформ (30 квітня 2020 p.) <https://www.ukrinform.ua/rubric-society/3016937-ak-pracue-elektronnesudocinstvo-abo-vstati-sud-na- zvazku.html> accessed 23 January 2021.

14 The Order No. 169 (8 April 2020) by the State Court Administration of Ukraine (was revoked by the Order No. 196 (23 April 2020)/ Наказ Державної Судової Адміністрації України «Про затвердження Порядку роботи з технічними засобами відеоконференцзв'язку під час судового засідання в адміністративному, цивільному та господарському процесах за участі сторін поза межами приміщення суду» № 169 (8 квітня 2020 р.) Наказ втратив чинність згідно з Наказом Державної Судової Адміністрації № 196 від 23 квітня 2020 p. < https://dsa.court. gov.ua/userfiles/media/dsa_pres slujba_2019/dsa_pres_slujba_2020/N_169_20.pdf $>$ accessed 24 January 2021.

15 Talina Kravtsova, 'Partici pation in online hearing. Now it is possible!' Liga 360 (9 April 2020)/ Taліна Кравцова «Участь у судовому засіданні онлайн. Тепер це можливо!» Liga 360 (9 квітень 2020 р.) $<$ https://biz.ligazakon.net/analitycs/194450_uchast-u-sudovomu-zasdann-onlayn-teper-tse-mozhlivo> accessed 20 January 2021.

16 Op. cit. The Order No. 169/revoked by the Order No. 196 (23 April 2020) please see here < https:// ips.ligazakon.net/document/view/sa20011?an=1> accessed 24 January 2021. 
uninterrupted way. In response to the pandemic, besides the shift to remote case hearings, the so-called 'Nightingale' courts were introduced nationwide. To meet social distancing requirements, the courtrooms took place at venues such as town halls, theatres, a cathedral, a hotel and even at a university's premises. ${ }^{17}$

Professor Richard Susskind stated: «...The UK Supreme Court has responded more emphatically and successfully than any of its equivalents internationally. Thanks to technology, perseverance, and judicial adaptability, access to the highest court in the United Kingdom has been maintained during the crisis.» ${ }^{18}$ Susskind's words that the UK Supreme Court had made an efficient transition to working remotely, were also echoed by the lecture at the Annual Law Forum given by Lord Hodge, Deputy President of the UK Supreme Court, in which the Lord Justice emphasized the importance of adaptability to new working conditions and confirmed that successful virtual hearings were possible with the help of a strong IT team. The hearings were held on the Cisco Webex videoconferencing platform. Furthermore, to uphold the principle of open justice, the general public had access to the hearings through online streaming or recordings. There was no case which had had to be adjourned on the basis that a court was not able to hold a hearing, stated Lord Hodge. ${ }^{19}$
Preparedness for adversity does not come in one day. One reason for the efficient reaction to the lockdown in the UK was the UK government's allocation of $£ 1$ billion to technological upgrading of the justice system in 2016 in order to make court procedures more cost-effective and more accessible to its citizens. ${ }^{20}$ In the Ministry of Justice report 'Transforming Our Justice' (September 2016), the importance of technology in shaping the future of the judicial system was emphasized with examples including development of a single online system for case management across criminal, civil, family and tribunal jurisdictions as well as the introduction of virtual hearings by telephone and videoconferencing amongst other media. ${ }^{21}$ To adapt to changing times, the judiciary system in the UK had thus already witnessed changes before the pandemic took place and was therefore better able to tackle the issues presented by the pandemic.

The current state of digitalization in the justice system may serve as a transition to an even more advanced form of justice - the Online Court, the concept of which was proposed by Lord Briggs in

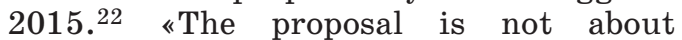
digitalization of the current system but 'a new, more investigative, court designed for navigation without lawyers' (page 36 para 6.2).» 23 The concept of an Online Court involves the creation of a wholly new court with its own simplified rules

17 Tristan Kirk, 'New 'Nightingale' courts open in the High Court in London in coronavirus pandemic response' Evening Standard (11 January 2020) <https://www.standard.co.uk/news/crime/nightingale-court-highcourt-coronavirus-pandemic-b823493.html> accessed 24 January 2021.

18 Richard Susskind cited in 'Covid, continuity and change: the court's response to the pandemic' Lord Hodge, Deputy President of the UK Supreme Court, British Irish Commercial Bar Association Annual Law Forum (5 November 2020) <https://www.supremecourt.uk/docs/BICBA\%20Annual\%20Law\%20Forum\%20\%20lecture\%2011.20.pdf> accessed 23 January 2021

19 Ibid.

20 Professor Derrick Wyatt 'In the UK the Covid-19 lockdown has accelerated the use of virtual court hearings but will it bring permanent changes to the judicial process?' Fide <https://www.fidefundacion.es/In-the-UK-theCovid-19-lockdown-has-accelerated-the-use-of-virtual-court-hearings-but-will-it-bring-permanent-changes_a1359.h tml> accessed 24 January 2021.

21 The Ministry of Justice 'Transforming our Justice System' by the Lord Chancellor, the Lord Chief Justice and the Senior President of Tribunals (September 2016) <https://assets.publishing.service.gov.uk/government/ uploads/system/uploads/attachment_data/file/553261/joint-vision-statement.pdf> accessed 24 January2021.

22 Lord Justice Briggs, Civil Courts Structure Review Final Report (July 2016) < https://www.judiciary. uk/ wp-content/uploads/2016/07/civil-courts-structure-review-final-report-jul-16-final-1.pdf> accessed 24 January 2020.

23 Lord Justice Briggs cited in Diane Astin, 'Navigation without lawyers': access to justice and the online court' LAG (October 2016) <https://www.lag.org.uk/article/202069/-lsquo-navigation-without-lawyersrsquo-access-to-justice- and-the-online-court> accessed 23 January 2021. 
which would deal with civil claims with a

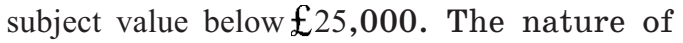
this court, undoubtedly, has raised concerns amongst lawyers as it will place certain legal professions at risk by enabling citizens to solve disputes directly with the help of technology in a question-answer format. They have been reassured that the process will not fully exclude legal professionals. It will involve three stages, wherein the first stage will establish the matter by the court putting questions to which the client should answer (technology and client interaction). The second stage is a case management and reconciliation stage, which will be conducted online or by a phone call with the help of court administrators. Parties will be entitled to ask for the decision to be reconsidered by the judge. If at stage two the case has not been settled, it will proceed to stage three, where the actual case hearing will take place over the phone or video but with strict time limits. ${ }^{24}$

In his recent book entitled 'Online Courts and the Future of Justice' Richard Susskind illustrates how the justice system will be transformed by technology, citing an example of online courts with human judges as well as forecasting "court determinations being made by AI-based system'. ${ }^{25}$ While this development, according to Susskind's view, is a likely future for the courts, China proves that it is already a reality.

Through the state plan for transforming China into a 'cyber superpower', the Supreme Court of China established socalled Internet Courts in Hangzhou, Beijing and Guangzhou in 2017. ${ }^{26}$ These Internet Courts are designed to deal with a range of Internet-related disputes including e-commerce, intellectual property rights ownership and infringement, infringement of personal rights or property rights on the Internet and product liability claims. ${ }^{27}$ The Internet Courts are said to be cost-as well as time-effective; the whole litigation process takes place online from filing the documents, to the hearing and judgement, to appeals. ${ }^{28} \mathrm{~A}$ Hangzhou Court official reported that the Internet Court system works 24 hours, 7 days a week ${ }^{29}$ making the justice system accessible as never before.

According to Vivien and Co, a China law firm, evidence in cases trialed in the Internet Courts is being generated and stored in a new, tamper-proof way with the help of blockchain technology. ${ }^{30}$ This simplifies the process as the evidence saved in the blockchain does not require a notary public to validate it and the cost for collecting blockchain evidence is lower compared with notarization. In addition, it is possible to combine online monitoring and collection of evidence in one process. For instance, if monitoring of intellectual property online identifies infringements, evidence will be saved in the blockchain automatically. Because of the tamper-free nature of the blockchain technology, the admissibility of blockchain evidence has been allowed by law and courts in China. ${ }^{31}$

China's established position in the world of Artificial Intelligence development and its promotion of smart technology across various sectors of life, including the

24 Joshua Rozenberg QC, 'The Online Court: will IT work?' The Legal Education Foundation <https:// long-reads.thelegaleducationfoundation.org/how-will-online-courts-work/> accessed 24 January 2021.

25 Richard Susskind <https://www.susskind.com> accessed 24 January 2021.

26 Sophie Hunter, 'China's innovative Internet Courts and their use of blockchain backed evidence' Conflict of Laws (28 May 2019) <https://conflictoflaws.net/2019/chinas-innovative-internet-courts-and-their-use-of-blockchainbacked-evidence/> accessed 24 January 2021.

27 Ibid.

28 Mimi Zou, ‘"Smart Courts» in China and the future of personal injury litigation' Journal of Personal Injury Law (June 2020) Oxford University Press < https://papers.ssrn.com/sol3/papers.cfm?abstract_id=3552895> accessed 23 January 2021.

29 Tara Vasdani, 'Robot justice: China's use of Internet courts' LexisNexis <https://www.lexisnexis.ca/en-ca/ ihc/2020-02/robot-justice-chinas-use-of-internet-courts.page> accessed 24 January 2021.

30 Vivien Chan and Anna Mae Koo, 'Blockchain Evidence in Internet Courts in China: the Fast Track for Evidence Collection for Online Disputes' Lexology (15 July 2020) < https://www.lexology.com/library/detail.aspx?g= 1631e87b- 155a-40b4-a6aa-5260a2e4b9bb> accessed 24 January 2021.

31 Ibid. 
judiciary, has not stopped solely at Internet Courts but has moved forward towards the introduction of Smart Courts. This latest creation gives us a glimpse into what the future digitalization of justice might look like. Smart Courts, like Internet Courts, take place outside of the traditional physical courtrooms, but compared with the Internet Courts, they have no human judge. Instead, cases are trialed by a virtual 'judge' powered by Artificial Intelligence and portrayed in the system as a man wearing a black robe. ${ }^{32}$ So, how does it actually work and who makes the decisions in cases? Straton Papagianneas, in his article 'Smart Courts: toward the digitalization and automation of justice', 33 explains that a key point of the mechanism behind the Smart Court is a human-computer interaction based on various technological applications that can 'automatically prompt similar cases as a reference for judges, to systems that can process and cross-examine all collected evidence, to ones that can automatically detect contradictions or relevant information for the judge to review.' ${ }^{34}$ Therefore, it is still a human judge that makes a decision, although with substantial help from smart technology.

Although all these technological developments in the judiciary have helped, internationally, to uphold court processes during the pandemic, it should be noted that virtual courts do not fit all types of cases. For instance, family law and criminal law matters have proved to be best trialed in traditional, physical, courts. According to a survey by the
Nuffield Family Justice Observatory, a UK charity, lawyers and clients reported that family-related disputes require an 'empathetic and humane' approach, which is hard to achieve with technology and without the presence of a real human contact. ${ }^{35}$ Families have expressed their concerns that, due to insufficient access to their legal representatives before the virtual hearings and inability to speak before the judge, the outcome in their cases could have been affected. In criminal proceedings, there are also a number of challenges presented by virtual hearings, ranging from inability to read non-verbal cues and emotions, the questionable credibility of given testimony online from home, ${ }^{36}$ and loss of sense of formal court procedures to issues related to the remote jury, such as technical disruptions or confidentiality. ${ }^{37}$

\section{Conclusion}

The COVID-19 lockdown accelerated the use of virtual court hearings across the globe. Richard Susskind, a strong proponent of online courts, in his article 'Covid-19 shutdown shows virtual courts work better' suggests that 'we should never return to the old ways'. ${ }^{38}$ However, virtual hearings, although technologically possible and time-and cost-effective, raise concerns as to whether they can best meet the interests of justice in all types of cases. Traditional courts, for example, may be preferable for criminal and family law cases.

Some steps have been taken to digitalize the justice system in Ukraine but it is still

\footnotetext{
32 Tara Vasdani op. cit.

33 Straton Papagianneas, 'Smart Courts: toward the digitalization and automation of justice' The China Story (21 August 2020) <https://www.thechinastory.org/smart-courts-toward-the-digitisationand-automation-of-justice/ $>$ accessed 24 January 2020.

34 Ibid.

35 Alice Blackwell, 'Most families facing virtual family court hearings concerned about handling of their case, study finds' (30 October 2020) CommunityCare <https://www.communitycare.co.uk/2020/10/30/ families-facing-virtual-family-court-hearings-concerned-handling-case-study-finds/> accessed 24 January 2021.

36 Jason Tashea, 'The legal and technical danger in moving criminal courts online' Tech Stream (6 August 2020) $<$ https://www.brookings.edu/techstream/the-legal-and-technical-danger-in-moving-criminal-courts-online/> accessed 24 January 2021.

37 Sarah Lloyd, 'Remote jury trials during Covid-19: what one project found about fairness and technology' The Conversation (16 July 2020) <https://theconversation.com/remote-jury-trials-during-covid-19-what-one-projectfound-about-fairness-and-technology-142505> accessed 24 January 2021.

38 Richard Susskind, 'Covid-19 shutdown shows virtual courts work better' Financial Times (7 May 2020) <https://www.ft.com/content/fb955fb0-8f79-11ea-bc44-dbf6756c871a> accessed 24 January 2021.
} 
in its infancy in contrast to the digital reality in China and the concept of an Online Court in the UK. However, there is a lot of potential in the country, which is developing and is open for opportunities in digital transformation. As can be seen with the earlier-created concept of ESITS/ E-court as well as court experiences in virtual hearings using EasyCon and other online platforms during the pandemic, the justice system of Ukraine has started the process of transition from traditional to virtual courts, although this process may take several years to gain momentum.

A nationwide electronic ESITS system with E-courts would be a desirable mechanism to incorporate into the Ukrainian justice system, which, arguably, should not replace the traditional courts but serve as an alternative to them. A significant step towards implementation of ESITS/E-court was made in December 2020 when the Parliament of Ukraine supported a bill with regard to the staged implementation of ESITS. If the relevant law is enacted, it will mean that ESITS will start working on a module-by-module basis without the necessity of waiting for a full-scale implementation. Of course, financial support will be required as well as technical expertise to make the system fully ready to function. Until that time, attention should be paid to the current issues related to virtual hearings, such as limited access to virtual justice due to difficulty in obtaining electronic signatures or limitations in the type of devices which can be used for virtual hearings. Of course, we should not forget that not every citizen in Ukraine has access to a computer or the Internet and this factor should also be taken into account when creating a digital future.

The pandemic has changed the way in which justice is delivered to the public and in which the judiciary operates. Courts will continue to face transformation and convergence into virtual mechanisms for delivering justice in a new, and arguably more convenient, way to the public. We must guarantee that this global change will meet the best interests of justice and that equal access to it will be provided for all.

\section{Selected Bibliographies}

\section{Laws and Regulations/Закони та нормативні акти}

The Law of Ukraine 540-IX dated 30 March 2020 'About amendment to certain legal acts in respect with provision of additional social and economic guarantees in relation with coronavirus (COVID-19) spread' / Закон України 540-XI «Про внесення змін до деяких законодавчих актів України, спрямованих на забезпечення додаткових соціальних та економічних гарантій у зв'язку з поширенням коронавірусної хвороби (COVID-19)»<https://zakon.rada.gov.ua/laws/ show/540-20\#Text>accessed/ дата звернення: 21 January 2021.

The Commercial Procedural Code of Ukraine/Господарський процесуальний кодекс України.

The Regulation of the Government of Ukraine № 211 dated 11 March 2020 'About prevention the spread of COVID-19 caused by coronavirus SARS-CoV-2 in the territory of Ukraine'/Постанова Кабінету Міністрів України від 11 березня 2020 р. № 211 «Про запобігання поширенню на території України гострої респіраторної хвороби COVID-19, спричиненої коронавірусом SARS-CoV-2» <https://zakon.rada.gov.ua/laws/show/211-2020-п\#Text> accessed/ дата звернення: 23 January 2021.

The Order No. 169 (8 April 2020) by the State Court Administration of Ukraine (was revoked by the Order No. 196 (23 April 2020)/ Наказ Державної Судової Адміністрації України «Про затвердження Порядку роботи з технічними засобами відеоконференцзв’язку під час судового засідання в адміністративному, цивільному та господарському процесах за участі сторін поза межами приміщення суду № 169 (8 квітня 2020 р.) Наказ втратив чинність згідно з Наказом Державної Судової Адміністрації номер 196 від 23 квітня 2020 p. <https://dsa.court.gov.ua/ userfiles/media/dsa_pres_slujba_2019/dsa_pres_slujba_2020/N_169_20.pdf $>$ accessed/дата звернення: 24 January 2021. 
12/2020 ISSN 2308-9636. Юридична Украӥна. 2020. № 12

\section{ІНФОРМАЦІЙНЕ ПРАВО}

Electronic articles/Електронні статті

Arsiriy A, 'Theory vs in practice: abilities of ESITS and «Electronic court» Yurydychna Gazeta online (24 November 2020)/Арсірій A, «В ідеалі vs на практиці: можливості ЄСITC та «Електронного суду» Юридична Газета online (24 листопада 2020 p.) <https://yur-gazeta.com/ publications/practice/sudova-praktika/v-ideali-vs-na-praktici-mozhlivosti-esits-ta-elektronnogosudu.html> accessed 24 January 2021

Astin D, 'Navigation without lawyers': access to justice and the online court' LAG (October 2016)/Астін Д, «Навігація без адвокатів: доступ до правосуддя та Інтернет-суду» Лаг (жовтень, 2016 p.) <https://www.lag.org.uk/article/202069/-lsquo-navigation-without-lawyersrsquo-access-to-justice-and-the-online-court> accessed/дата звернення: 23 Јanuary 2021.

Blackwell A, 'Most families facing virtual family court hearings concerned about handling of their case, study finds' (30 October 2020) Community Care/Блеквел А, «Як показує дослідження, більшість сімей, які стикаються з віртуальними сімейними судовими засіданнями, стурбовані розглядом їх справи" (30 жовтня 2020 р.) Ком'юніті Кеа

$<$ https://www.communitycare.co.uk/2020/10/30/families-facing-virtual-family-court-hearin gs-concerned-handling-case-study-finds/> accessed/ дата звернення: 24 Јanuary 2021.

Chan V., Koo A. M, 'Blockchain Evidence in Internet Courts in China: the Fast Track for Evidence Collection for Online Disputes' Lexology (15 July 2020)/Чен B., Ку А. М, «Докази блокчейн в Інтернет-судах Китаю: швидкий шлях до збору доказів для онлайн-суперечок» Лексолоджі (15 липня 2020 р.).

$<$ https://www.lexology.com/library/detail.aspx?g=1631e87b-155a-40b4-a6aa-5260a2e4b9bb> accessed/ дата звернення: 24 January 2021.

Wyatt D, 'In the UK the Covid-19 lockdown has accelerated the use of virtual court hearings but will it bring permanent changes to the judicial process?' Fide/Ваят Д, «У Великобританіi локдаун Covid-19 прискорив використання віртуальних судових засідань, але чи внесе це постійні зміни до судового процесу?»<https:/ www.fidefundacion.es/In-the-UK-the-Covid-19 lockdown-has-accelerated-the-use-of-virtual-court-hearings-but-will-it-bring-permanent-changes a1359.html> accessed/ дата звернення: 24 January 2021.

'Electronic queue' Court Messenger 4 (29 Мау 2020)/ «Електронна черга» Судовий Вісник 4 (29 травня 2020 р.) <https://pravo.ua/articles/elektronna-cherga-2/> accessed/ дата звернення: 23 January 2021.

Hunter S, 'China's innovative Internet Courts and their use of blockchain backed evidence' Conflict of Laws (28 May 2019)/ Хантер С, «Інноваційні Інтернет-суди Китаю та використання ними доказів підтверджених блокчейном» Конфлікт оф Лоз (28 травня 2020 р.) <https:// conflictoflaws.net/2019/chinas-innovative-internet-courts-and-their-use-of-blockchain-backed-e vidence/> accessed/ дата звернення: 24 January 2021.

Kirk T, 'New 'Nightingale' courts open in the High Court in London in coronavirus pandemic response' Evening Standard (11 January 2020)/Кірк Т, «Нові суди «Найтінгейл» відкриваються у Високому суді Лондона у відповідь на пандемію коронавірусу» Івнінг Стендарт (11 січня 2020 р.)

$<$ https://www.standard.co.uk/news/crime/nightingale-court-high-court-coronavirus-pandem ic-b823493.html> accessed/дата звернення: 24 January 2021.

Kravtsova T, 'Participation in online hearing. Now it is possible!' Liga 360 (9 April 2020)/ Kpaвцова Т, «Участь у судовому засіданні онлайн. Тепер це можливо!» Liga 360 (9 квітень 2020 р.) $<$ https://biz.ligazakon.net/analitycs/194450_uchast-u-sudovomu-zasdann-onlaynteper-tse-mozhlivo> accessed/ дата звернення: 20 January 2021.

Lloyd S, 'Remote jury trials during Covid-19: what one project found about fairness and technology' The Conversation (16 July 2020)/Ллойд C, «Віддалені судові розгляди судом присяжних під час Covid-19: що один проект виявив щодо справедливості та технологій" Ди Конверсейшн (16 липня 2020 р.) < https://theconversation.com/remote-jury-trials-during-covid-19what-one-project-found-about-fairness-and-technology-142505> accessed / дата звернення: 24 January 2021.

Lord Hodge 'Covid, continuity and change: the court's response to the pandemic' Lord Hodge, Deputy President of the UK Supreme Court, British Irish Commercial Bar Association Annual Law Forum (5 November 2020)/Лорд Ходж «Ковід, безперервність та зміни: відповідь суду на пандемію» Лорд Ходж, заступник голови Верховного суду Великобританії, Щорічний юридичний форум Британської Ірландської Асоціації Комерційних Адвокатів (5 листопада 2020 p.)

<https://www.supremecourt.uk/docs/BICBA \% 20Annual \% 20Law $\%$ 20Forum $\% 20 \%$ 20lecture \% 2011.20.pdf> accessed/ дата звернення: 23 January 2021. 
Obuh V, 'How does the electronic justice work or 'Stand up! Court is on the line!' (30 April 2020) Ukrinform/ Обух В, «Як працюе судочинство або «Встати! Суд на звязку» Укрінформ (30 квітня 2020 p.) <https://www.ukrinform.ua/rubric-society/3016937-ak-pracue-elektronnesudocinstvo-abo-vstati-sud-na-zvazku.html> accessed/ дата звернення: 23 January 2021.

Papagianneas S, 'Smart Courts: toward the digitalization and automation of justice' The China Story (21 August 2020)/ Папагіанес C, «Розумні суди: до цифровізації та автоматизації правосуддя» Де Чайна Сторі (21 серпня 2020 р.) <https://www.thechinastory.org/smart-courtstoward-the-digitisation-and-automation-of-justice/> accessed/ дата звернення: 24 January 2020.

Roshchenko O, "Electronic court» will be released in parts: Rada allowed' Ukrainian Truth 16 December 2020/Рощенко О, «Електронний суд» запускатимуть частинами: Рада дозволила» Українська Правда (16 грудня 2020 р.) <https://www.pravda.com.ua/news/2020/12/16/ 7277151/> accessed/ дата звернення: 20 January 2020.

Rozenberg J, 'The Online Court: will IT work?' The Legal Education Foundation/

Розенберг Дж, «Інтернет-суд: чи працюватиме IT?» Ди Лігал Ед’юкейшн Фаундейшн <https://long-reads.thelegaleducationfoundation.org/how-will-online-courts-work/>accessed/ дата звернення: 24 January 2021.

Susskind R, 'Covid-19 shutdown shows virtual courts work better' Financial Times (7 May 2020)/Сускінд Р, «Локдаун Ковід-19 показує, що віртуальні суди працюють краще» Файненшел Таймс (7 травня 2020 р.)

<https://www.ft.com/content/fb955fb0-8f79-11ea-bc44-dbf6756c871a> accessed/ дата звернення: 24 January 2021.

Tashea J, 'The legal and technical danger in moving criminal courts online' Tech Stream (6 August 2020)/Таше Дж, «Правові та технічні ризики перенесення судів з кримінальних справ онлайн» Тех Стрім (6 серпня 2020 p.) <https://www.brookings.edu/techstream/ the-legal-and-technical-danger-in-moving-criminal-courts-online/> accessed/ дата звернення: 24 January 2021.

Trut D., Avtuh A, ‘Advantages of electronic justice. We are going on time!' Lawyer \& Law/Liga 45 / Трут Д., Автух А, «Переваги електронного судочинства. Ідемо в ногу з часом!» Юрист \& Закон Ліга <https://uz.ligazakon.ua/ua/magazine_article/EA009834> accessed/дата звернення: 22 January 2021 .

Vasdani T, ‘Robot justice: China's use of Internet courts' LexisNexis/ Ваздані Т, «Робот-правосуддя: використання Китаєм Інтернет-судів» ЛексісНексіс <https://www.lexisnexis.ca/ en-ca/ihc/2020-02/robot-justice-chinas-use-of-internet-courts.page > accessed/ дата звернення: 24 January 2021.

Zou M, "Smart Courts» in China and the future of personal injury litigation' Journal of Personal Injury Law (June 2020) Oxford University Press/ Дзоу М, «Розумні суди в Китаї та майбутнє судового справ про тілесні ушкодження» Джорнал оф Песонал Інджурі Ло (червень 2020 p.) <https://papers.ssrn.com/sol3/papers.cfm?abstract_id=3552895> accessed/ дата звернення: 23 January 2021.

\section{Reports/Звіти}

Lord Justice Briggs, Civil Courts Structure Review Final Report (July 2016)/Лорд Джастіс Брігс Підсумковий Звіт Структури Цивільних Судів (липень 2016) <https://www judiciary.uk/wp-content/uploads/2016/07/civil-courts-structure-review-final-report-jul-16-final -1.pdf> accessed/дата звернення: 24 January 2020.

The Ministry of Justice Report 'Transforming our Justice System' by the Lord Chancellor, the Lord Chief Justice and the Senior President of Tribunals (September 2016)/ Звіт Міністерства Юстиції «Трансформація нашої системи правосуддя» Лорд-Канцлер, Лорд-Головний Суддя та Старший Президент Трибуналів (вересень 2016 р.)

$<$ https://assets.publishing.service.gov.uk/government/uploads/system/uploads/attachment data/file/553261/joint-vision-statement.pdf> accessed/дата звернення: 24 January 2021.

\section{Websites/веб-сайти}

The High Council of Justice of Ukraine/Вища Рада Юстиції України <https://hcj.gov.ua/ news/vrp-nadala-sudam-rekomendaciyi-shchodo-zabezpechennya-stabilnoyi-roboty-v-umovah-kar antynu> accessed/дата зверення: 21 January 2021.

'I dream about the state in a smartphone - Volodymyr Zelensky' (23 Мау 2019) «Я мрію про державу у смартфоні - Володимир Зеленський» <https://www.president.gov.ua/news/ya-mriyu-proderzhavu-u-smartfoni-volodimir-zelenskij-55585> accessed/дата звернення: 23 January 2021.

<https://www.susskind.com> accessed/дата звернення: 24 January 2021.

Step-by-step Instructions for registration in E-court: < https://zp.arbitr.gov.ua/sud5009/ gromadyanam/el-sud-reg/> accessed 24 January 2021. 
Журавель М. В. Перехід традиційного судочинства до віртуальних судів: реальність чи міф для системи правосуддя в Україні?

Панделія COVID-19 спричинила численні труднощі в юрисдикцілх по всьолу світу та прискорила процеси цифровізащї правосуддя. У той час, як світ зіштовхнувся з величезними проблелали, спричиненими панделією, і срера охорони здоров'я у різних країнах налагалася впоратися зі зростаючою кількістю хворих на коронавірус, систела судочинства також зазнала чилалих викликів під час національних локдаунів. Для надання гроладянал безперервного доступу до судочинства зали судових засідань залишалися відкритили, хоча й у новолу, віртуальному режимі, за пред’явленням електронного підпису, як ие було зроблено в Україні. Раніше створена концепція Єәиної судової інформаційно-телеколунікаційної систели (ССITC) та підсистели електронного суду могла б послугувати корисним иілям у ией кризовий час, але через технічні проблеми вона зазнала поразки ще задовго до настання кризи. Таким чинол, суддял довелося застосовувати інші засоби для проведення віртуальних слухань справ, такі як EasyCon, Skype та Zоoт, хоча иі програли виявилися не без недоліків. Проте спеціалісти в інфорлаційних технологіях плідно працюють над тим, щоб покращити досвід у використанні різних програл для забезпечення ефективного судочинства у віртуальнолу режилі, яке $\epsilon$ ключовим в епоху кризи. Ця стаття має на меті проаналізувати ситуацію, з якою зіштовхнулася судова система в Україні за часів пандемії, звертаючи увагу на необхідність подальшого впровадження ССІТС у дію як альтернативу традиційному судочинству. Також будуть зроблені посилання на зарубіжну практику у віртуальних розглядах справ у таких краӥнах як Великобританія та Китай. Як підсулок, буде надана авторська дулка щодо перспективи розвитку віртуального судочинства в Україні.

Ключові слова: систела правосуддя, СCITC, E-court, віртуальні слухання, традиційні суди, Інтернет-суд, панделія COVID-19, розулні суди, иирровізація.

Журавель М. В. Переход традиционного судопроизводства к виртуальным судам: реальность или миф для системы правосудия в Украине?

Пандемия COVID-19 вызвала трудности в юрисдикииях по вселу миру и ускорила проиессы иифровизации судопроизводства. В то вреля, как мир испытывал огролные бед ствия, а мировые систелы здравоохранения с трудом справлялись с растущил числом пациентов с коронавирусол, систела правосудия также столкнулась с лногочисленныли проблелали во вреля различных национальных локдаунов. Поскольку поддержание верховенства права через доступ $к$ правосудию в ходе справедливого судебного разбира тельства ни при каких обстоятельствах не должно быть прекращено, заль судебных заседаний оставались открытыли, хотя и в новол, виртуальном режиле, с предьявлениел әлектронной подписи, как свидетельствует опыт в Украине. Ранняя кониепиия ЕСИТС и электронного суда могла бы послужить полезной иели во время кризиса, но она потерпела неудачу из-за технических проблел и поэтолу не была полностью введена в действие. Таким образол, судьям пришлось изучить другие средства для дистаниионного проведения судебных заседаний, такие как EasyCon, Skype или Zоот. Цель данной статьи - проанализировать ситуацию, с которой столкнулась судебная систела в Украине во время пандемии, обращая внимание на необходилость дальнейшей разработки и приведение ЕСИТС в действие. Также будет рассмотрен опыт проведения вир туальных судебных заседаний в таких странах как Великобритания и Китай. В заключение, будет представлена авторская точка зрения касательно перспективы развития виртуального судопроизводства в Украине.

Ключевые слова: система судопроизводства, ЕСИТС, E-court, виртуальные судебные заседания, традиционные суды, онлайн-суд, панделия COVID-19, умные суды, иифровизация. 